http://jmscr.igmpublication.org/home/ ISSN (e)-2347-176x ISSN (p) 2455-0450 crossref DOI: https://dx.doi.org/10.18535/jmscr/v7i8.137

\title{
Fine Needle Aspiration Cytology: A Reliable Tool for Diagnosis of Spectrum of Breast Lesions in females in a Tertiary Care Teaching Hospital in Chamba District
}

\author{
Authors \\ Nidhi Gupta ${ }^{1}$, Heena Raina ${ }^{2}$, Mamta Gupta ${ }^{3}$, Kamna Singh ${ }^{4}$ \\ ${ }^{1}$ Senior Resident, Department of Pathology, Government Medical College, Kathua \\ ${ }^{2}$ Junior Resident, Department of Pathology, GMC, Jammu \\ ${ }^{3}$ Junior Resident, Department of Anaesthesia, ASCOMS, Jammu \\ ${ }^{4}$ Senior Resident, Department of Community Medicine, Government Medical College, Kathua
}

\begin{abstract}
Introduction: Breast or mammary gland is under the influence of hormones resulting in physiological changes throughout reproductive life and thereafter various structures give rise to different lesions. FNAC can be used as an OPD procedure in diagnosis of breast lesions without the need to hospitalize the patient.

Aim: To study the spectrum of breast lesions.

Methods: Breast Lump is the commonest presenting symptom in various types of Breast lesions ranging from inflammation to carcinoma.

Result: The most common lesion encountered in our study on FNAC was fibroadenoma (49.24\%) followed by benign proliferative mammary lesion $15.15 \%$. Tuberculous mastitis was 3.78\%. Malignancy was $7.57 \%$ Conclusion: Benign breast lesions form the bulk in this study and fibroadenoma is the most common lesion. FNAC is useful and reliable in early diagnosis of neoplastic and non-neoplastic lesions avoiding the need of biopsy. It has an important role in rural and semi-urban areas with fewer facilities and for the poor.
\end{abstract}

Keywords: Breast, Benign, FNAC, Fibroadenoma, carcinoma.

\section{Introduction}

In recent years, the focus on breast cancer has shifted from treatment to early diagnosis with the detection of proliferative breast or borderline breast diseases gaining importance in the approach of breast cancer. ${ }^{[1]}$ The various advantages of FNAC over biopsy in terms of cost effectiveness, improved patient satisfaction and low complication rate have made it an important first line method of cellular diagnosis of breast lesions. The accuracy rate ranges from just over
$50 \%$ to $95 \%$ depending on the experience of the aspirator and the interpreter. ${ }^{[2]}$ The current study was carried out with aim of studying the frequency of various breast lesions on FNAC in Department of Pathology, Pt. Jawahar Lal Nehru Government Medical College, Chamba, H.P.

\section{Methods}

The present study was a prospective study carried in Department of Pathology, Pt. Jawahar Lal Nehru Government Medical College during one 


\section{JMSCR Vol||07||Issue ||08||Page 809-815||August}

year study period and included 150 patients who presented with palpable breast lump. Cases diagnosed or referred from outside hospital were not included in the study. Detailed clinical history, physical examination were noted. Lump was examined for site and size, Nipple and Axilla on same side for Lymph nodes. Contralateral Breast, Nipple and axilla were also examined. Sonography was performed in cases where definite diagnosis was not possible on FNA. All the patients underwent FNA in cytology section after prior written consent. FNA was done with standard technique and aseptic precautions by using $20 \mathrm{cc}$ disposable syringe. Material was smeared on glass slides. Slides were stained with Giemsa stain and Ziehl Nelson (ZN) staining was done wherever required. In case, material obtained was not satisfactory, a repeat aspiration was done. In case of more than one swelling, aspiration was done from each swelling.

\section{Results}

Of the 150 cases, in 135 cases, the aspirates were adequate for interpretation and in 15 cases they were inadequate with very scanty cellularity or were only hemorrhagic. The age distribution of females were as follows. Maximum patients $(44 \%)$ in females were in the age group 21-30 years followed by age group 31-40 years. The oldest patient was 80 years old. (Table 1, Fig 1) Upper outer quadrant was the commonest site of location of lump in maximum number of patients (45\%).Left breast was more commonly affected than right breast. Upper outer quadrant was the commonest site of location in both breasts. On cytological evaluation $81.33 \%$ lesions were benign, $6.66 \%$ lesions were malignant, $1.33 \%$ lesions were atypical and $0.66 \%$ lesions were suspicious for malignancy. (Table 2, Fig 2)In benign inflammatory lesions maximum no. of cases were of breast abscess (7.57\%). 05 cases were diagnosed as Tuberculous mastitis. ZN stain was applied to all of them. In the present study, most common lesion was fibroadenoma in the age group 21-30 years. Fibroadenoma $n=65$ (49.24\%) patients were correlated with clinical setting and physical findings. They had solitary firm highly movable mass whereas patients of fibroadenosis had diffused lump or nodularity associated with pain. Suspicious cases were confirmed by histopathology. One case diagnosed as suspicious for malignancy. Out of 2 cases of atypical ductal hyperplasia, only one of them underwent biopsy. $\mathrm{N}=10$ were diagnosed ductal carcinoma in situ.

(Table 3, Fig 3)

Table 1: Age wise Distribution

\begin{tabular}{|l|c|c|}
\hline Age Group (in yrs ) & No. of females & Percentage \\
\hline $0-10$ & - & \\
\hline $11-20$ & 15 & $10 \%$ \\
\hline $21-30$ & 66 & $44 \%$ \\
\hline $31-40$ & 46 & $30.66 \%$ \\
\hline $41-50$ & 10 & $6.66 \%$ \\
\hline $51-60$ & 06 & $4 \%$ \\
\hline $61-70$ & 03 & $2 \%$ \\
\hline $71-80$ & 04 & $2.66 \%$ \\
\hline
\end{tabular}

Table 2: Categorization of Cytological lesions

\begin{tabular}{|l|c|c|c|}
\hline S.No & Category & $\begin{array}{c}\text { No. of } \\
\text { Patients }\end{array}$ & Percentage \\
\hline 1. & Benign & 122 & $81.33 \%$ \\
\hline 2. & Atypical & 02 & $1.33 \%$ \\
\hline 3. & Suspicious & 01 & $.66 \%$ \\
\hline 4. & Malignant & 10 & $6.66 \%$ \\
\hline 5. & $\begin{array}{c}\text { Inadequate/ } \\
\text { Hemorrhagic }\end{array}$ & 15 & $10 \%$ \\
\hline
\end{tabular}

Table 3: Distribution of Breast Lesions

\begin{tabular}{|l|c|c|c|}
\hline S.No & Lesions & $\begin{array}{c}\text { No. of } \\
\text { Patients }\end{array}$ & Percentage \\
\hline 1. & Fibroadenoma & 65 & $49.24 \%$ \\
\hline 2. & $\begin{array}{c}\text { Benign proliferative } \\
\text { Breast lesion }\end{array}$ & 20 & $15.15 \%$ \\
\hline 3. & Fibrocystic Disease & 14 & $10.60 \%$ \\
\hline 4. & Breast Abscess & 10 & $7.57 \%$ \\
\hline 5. & $\begin{array}{c}\text { Ductal Carcinoma } \\
\text { Breast }\end{array}$ & 10 & $7.57 \%$ \\
\hline 6. & $\begin{array}{c}\text { Tuberculous } \\
\text { Mastitis }\end{array}$ & 05 & $3.78 \%$ \\
\hline 7. & Galactocoele & 03 & $2.27 \%$ \\
\hline 8. & Fat necrosis & 02 & $1.51 \%$ \\
\hline 9. & $\begin{array}{c}\text { Epidermal Inclusion } \\
\text { Cyst }\end{array}$ & 02 & $1.51 \%$ \\
\hline 10. & $\begin{array}{c}\text { Atypical Ductal } \\
\text { Hyperplasia }\end{array}$ & 02 & $1.51 \%$ \\
\hline 11. & Lipoma & 01 & $0.75 \%$ \\
\hline 12. & $\begin{array}{c}\text { Suspicious for } \\
\text { mailgnancy }\end{array}$ & 01 & $0.75 \%$ \\
\hline
\end{tabular}




\section{JMSCR Vol||07||Issue||08||Page 809-815||August}

\section{AGE WISE DISTRIBUTION}

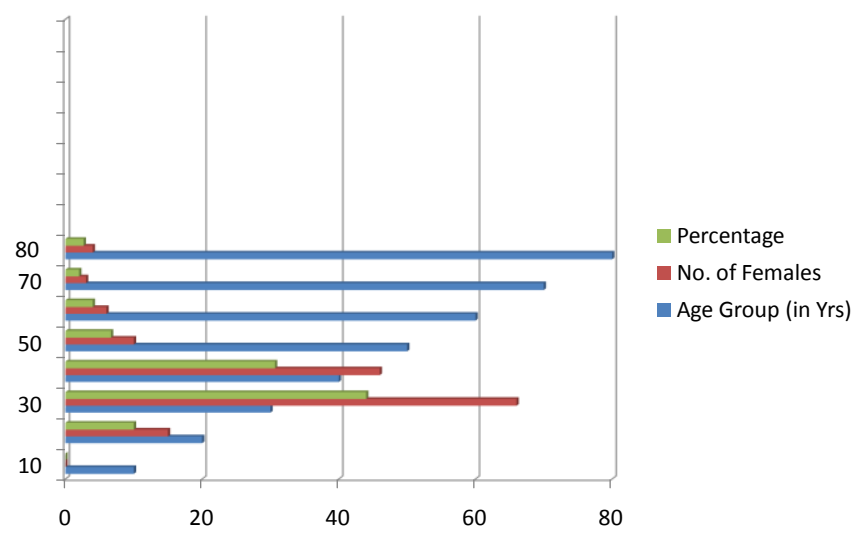

Fig 1 : Showing age wise distribution of females

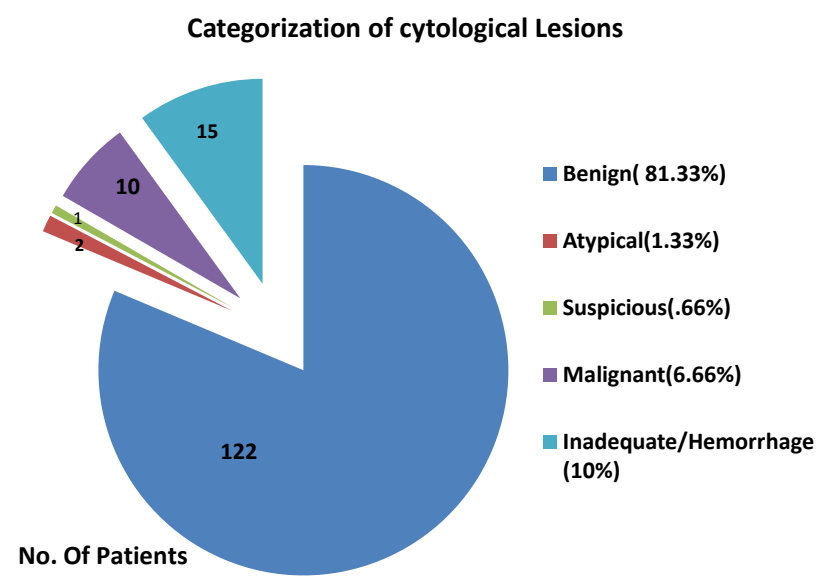

Fig 2: Showing categorization of cytological lesions
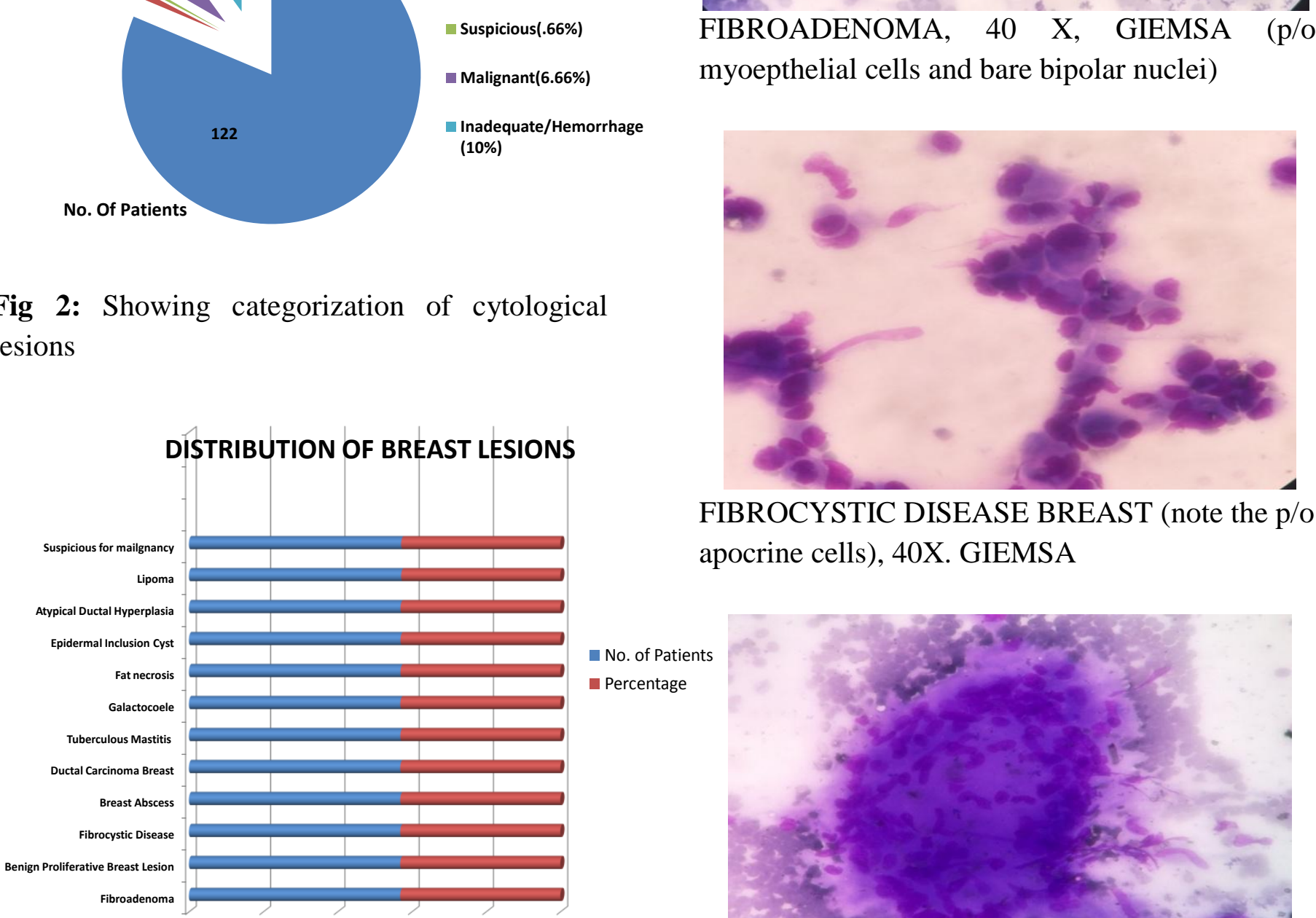
myoepthelial cells and bare bipolar nuclei)

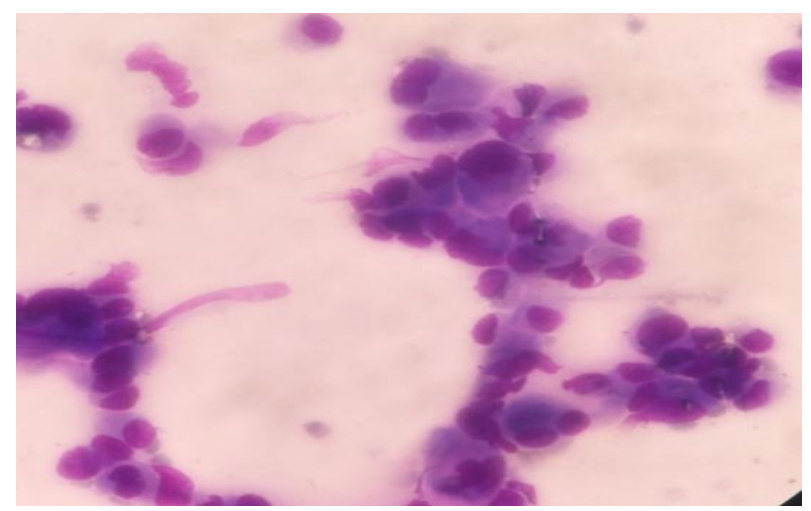

FIBROCYSTIC DISEASE BREAST (note the p/o apocrine cells), 40X. GIEMSA

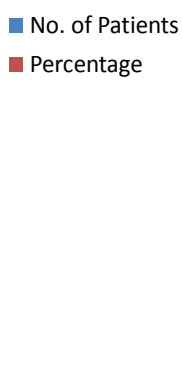

Fig 3: Showing distribution of Breast lesions

GRANULOMA (TB BREAST), 40 X, GIEMSA 


\section{JMSCR Vol||07||Issue||08||Page 809-815||August}

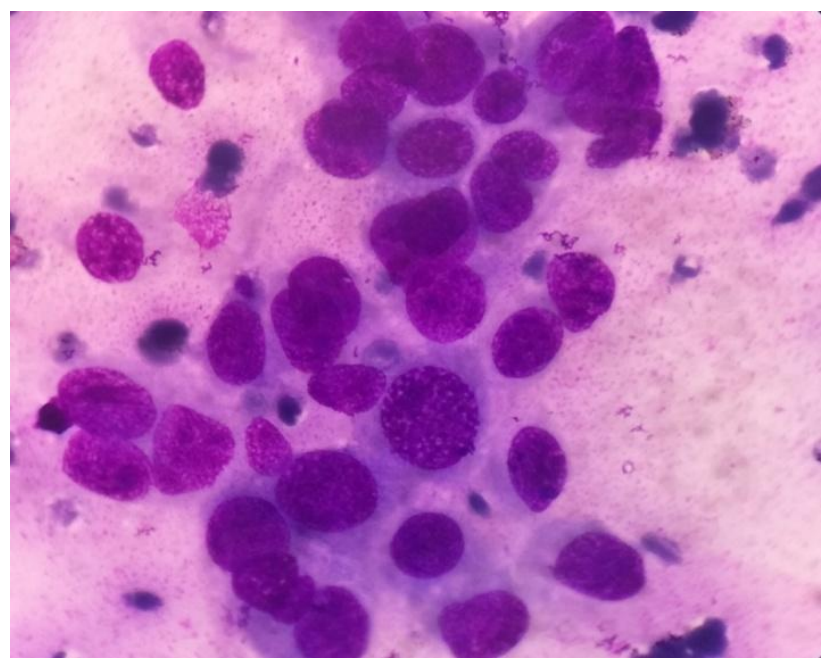

DUCTAL CARCINOMA, BREAST WITH PROMINENT NUCLEOLI. 40 X, GIEMSA

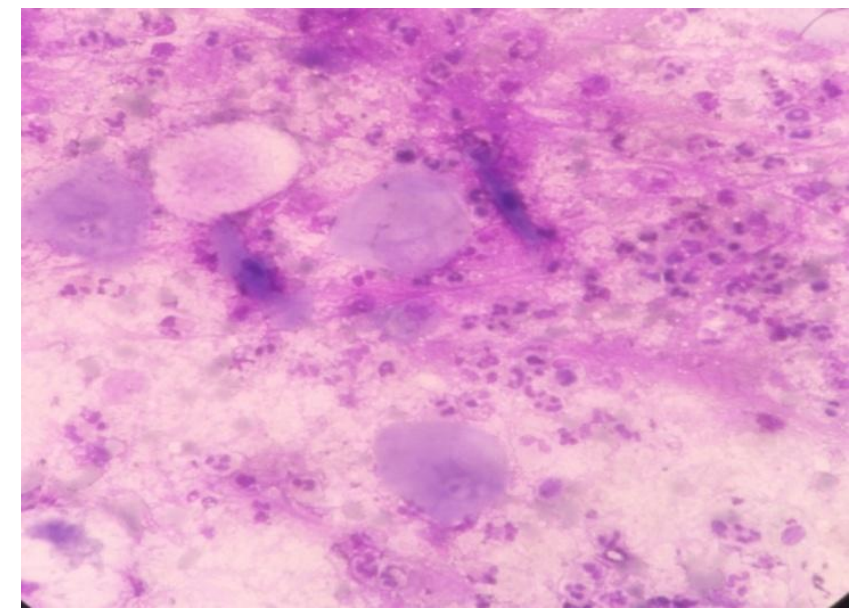

BREAST ABSCESS WITH P/0 NEUTROPHILS, 40X, GIEMSA

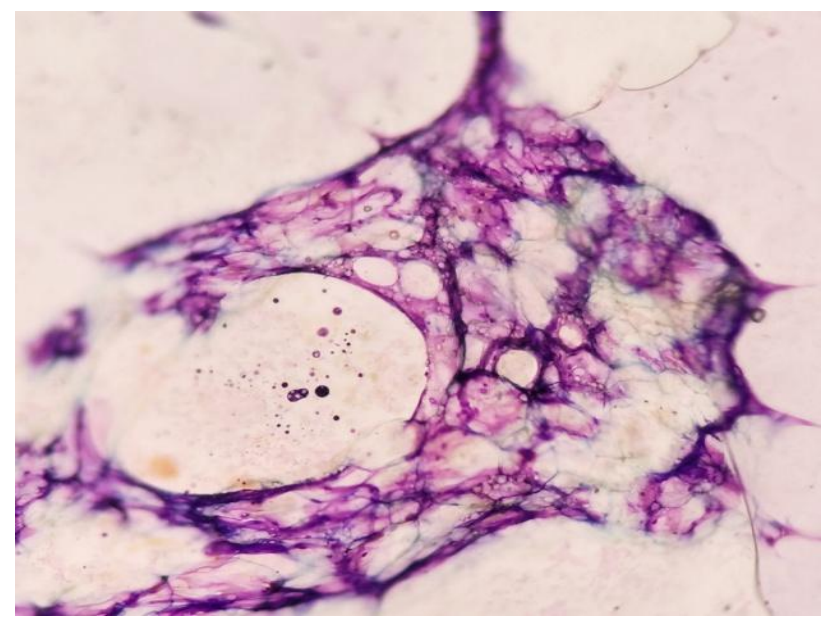

LIPOMA, BREAST, 40 X, GIEMSA

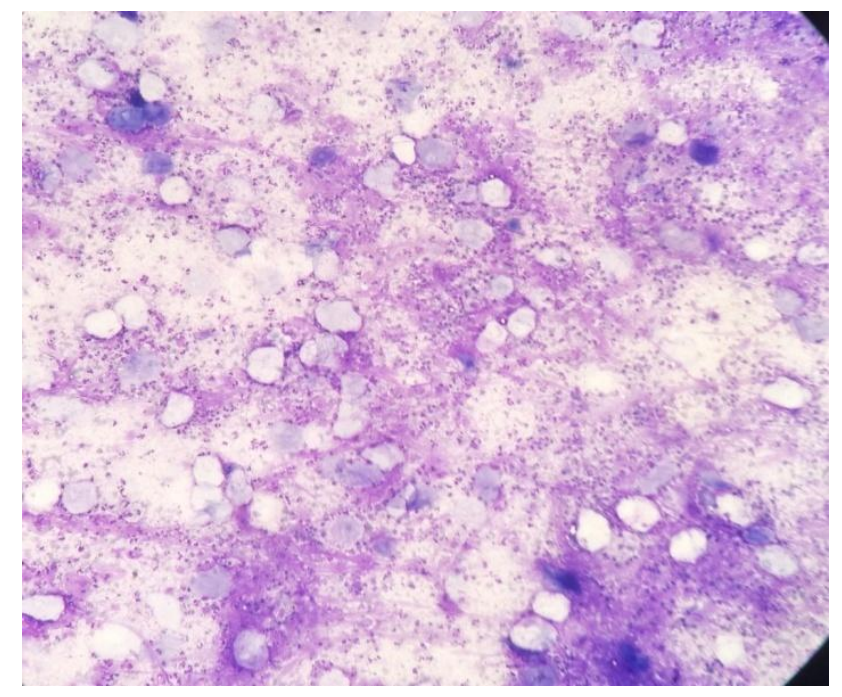

INFECTED EPIDERMAL INCLUSION CYST (p/o Squames), 10x. GIEMSA.

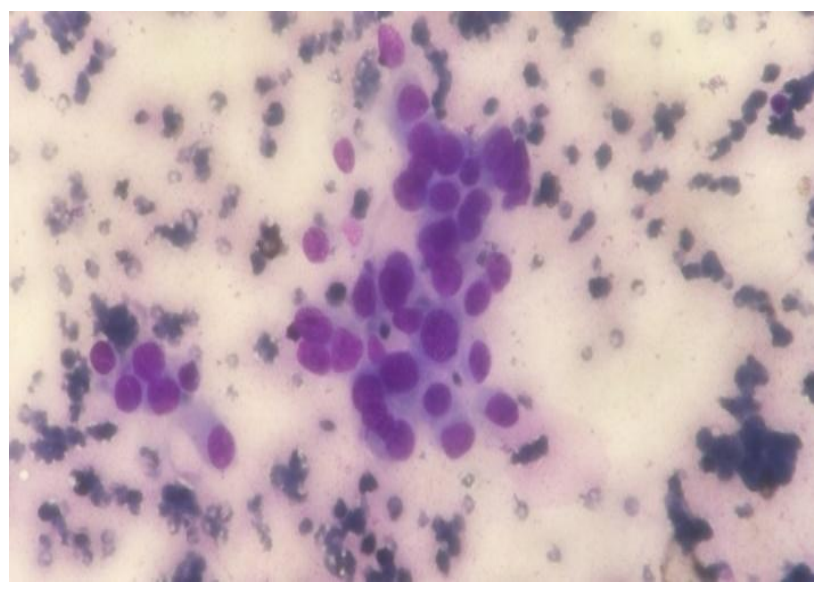

BENIGN PROLIFERATIVE BREAST LESION, 40X, GIEMSA

\section{Discussion}

The primary goal of FNA is to separate benign and malignant lesions so that early diagnosis helps in management and reduces morbidity and mortality. Breast diseases are more common in women because estrogen cyclically stimulates breast during their reproductive life. The youngest patient in the study were two 11 years old female with fibroadenoma and oldest female was 80 years old female with carcinoma breast. The most common age group involved in our study includes females of 21-30 years age group. Similar findings were observed by Farkhanda and coauthors and Godwin E et al. ${ }^{[3,4]}$ Haque et al have reported 30,40 years age group as the most common age group in their study. ${ }^{[5]}$ In our study 
this is the second most commonly involved age group. Involvement of left breast is more common in our study and this was also observed by Prakash et al whereas Chandanwale $S$ found the involvement of right breast more common. ${ }^{[6,7]}$

In the benign category, inflammatory lesions accounted for $5 \%$. The findings are very near to those observed by Chandanwale $\mathrm{S}$ and Baptist et al of $11 \%$ inflammatory lesions. ${ }^{[7,8]}$ In our study benign lesions were maximum $(85.86 \%)$. They were 7 times more common than malignant lesions. M. Kumar et al also reported the same. ${ }^{[9]}$ $\mathrm{He}$ asserted that in Indian rural population the benign breast diseases are 5 to 10 times more common than breast cancers. They stated that incidence of benign conditions of breast are common in developing countries but due to lack of education women disregard the breast lump. Adesunkanmi et al, ${ }^{[10]}$ have reported $85.86 \%$ of benign lesions and Chandanwale $\mathrm{S}$ have reported $80 \%$ of benign lesions. ${ }^{[7]}$ Benign breast conditions causing lumps or tumours are quite common (American Cancer society 2002, Dolan 2002, Johnson 1999, Marchant 2002), with an estimated 9 out of 10 women showing benign tissue changes if tissue is examined microscopically (American Cancer society 2002). ${ }^{[11]}$ Of the benign lesions fibroadenoma was most common and constituted 47.81\%. Malik et al have reported $55 \%$ and Priyadarshni $\mathrm{J}$ et al have reported $57 \%$ of fibroadenom ${ }^{[12,13]}$ Incidence of fibroadenoma is highest in younger women under $30 .^{[11]}$ Second most common was benign proliferative mammary lesion. Fibrocystic disease was the most common but we didn't categorize it because of overlap in cytological features of benign proliferative lesion. All cases of galactocele $(4.97 \%)$ had history of lactation. Only one case of phyllodes tumor was diagnosed by FNA and it was confirmed on histopathology. In our study only one case of tuberculous mastitis diagnosed on the basis of $\mathrm{ZN}$ stain. This is because in India tuberculosis is very common. Chandanwale SS et al have reported an incidence of $20 \%$ in their study. ${ }^{[14]}$ Common sites for epidermal inclusion cyst are head, neck, trunk and extremities. Previous reports on epidermal cyst in breast is scanty and to date less than 46 cases have been reported. They remain underreported because of their insignificant clinical presentation. ${ }^{[14]}$ There were 132 male patients out of which 131 patients had gynaecomastia and one patient of 80 years had infiltrating ductal carcinoma. The youngest patient was of 13 years while the oldest patient was 92 years. Gynaecomastia in young age is related to hormonal pubertal changes whereas in later years, it may be caused by hormonally active tumors, cirrhosis or medications Maximum number of patients were in 11-20 years $(10.77 \%)$ age group in gynaecomastia. ${ }^{[15]}$ As per GLOBOCON 2015, estimated incidence is 155863 which is 10926 more than in 2012 and estimated mortality is 75957 which is 5739 more than that in 2012. In India, for every 2 women newly diagnosed with breast cancer, one lady is dying of it. ${ }^{[16]}$ There were 154 cases of breast malignancy which were diagnosed as ductal carcinoma in 151 cases, 2 cases were reported as lobular carcinoma and 1 mucinous carcinoma. Pradhan et al have reported $15.5 \%$ cases, Mayun et al have found $40 \%$ and Jain SB et al have reported $20 \%$ of malignancy. ${ }^{[17,18]}$ In our study malignancy is comparatively less as we have catered rural population. Mortality and incidence is relatively lower in developing countries and other parts of globe in comparison to western population. (Khan et al 2003). ${ }^{[19]}$ Balkrishna B Yeole et al in an epidemiological study compared the breast cancer incidence of various countries and found that incidence rates were very high in developed countries. ${ }^{[20]}$ The incidence of breast cancer increases with age, more common in urban population and in women of higher socioeconomic group. They also suggested that apart from genetic causes, change in life style is responsible for increase in incidence of malignant breast lesions. 


\section{Conclusion}

For diagnosing the nature of palpable breast lesions, FNAC is considered as a highly accurate procedure with sensitivity and specificity as high as $95 \%$. Its use has been recommended in literature as preliminary treatment on outpatient basis. Early diagnosis is of paramount importance to decrease the mortality and morbidity associated with these lesions. The ability of FNA to differentiate benign and malignant lesions coupled with high sensitivity and specificity gives psychological relief to the patient. When in doubt the investigations like mammography and tru cut biopsy can be used to differentiate between benign and malignant lesions. Majority of the lesions in their study were benign with fibroadenoma being the most commonly diagnosed lesion. Although endocrine factors play a major role in etiology of benign breast lesions their exact role is still an enigma.

\section{References}

1. Strax P. Detection of breast cancer. Cancer 1990; 66: 13361340

2. Al Kaisi N. The spectrum of gray zone in breast cytology. A review of 186 cases of atypical and suspicious cytology. Acta Cytol.1994; 38:898-908.

3. Farkhanda JD, Muhammad SA, Ahsan AL, Noor MK, Imtiaz S, Zulfiqar IM. An early diagnosis of benign breast diseases. Journal of Surgery, Pakistan 2010; 15(4):74-78

4. Godwins E, David D, Akeem J. Histopathologic analysis of benign breast diseases in Makurdi, North Central Nigeria. International Journal of Medicine and Medical Sciences. 2011; 3(5): 125128.

5. Haque, Tyagi, Khan and Gahlut. Breast lesions: a clinico histopathological study of 200 cases of breast lump. JAMA 1980;150: 1810-1814.

6. Muddegowda PH, Lingegowda JB, Kurpad R, PG Konapur, AS Shivarudrappa and PM Subramaniam. The value of systematic pattern analysis in FNAC of breast lesions: 225 cases with cytohistological correlation. J Cytol 2011; 28(1): 13-19.

7. Chandanwale S, Rajpal M, Jadhav P, Sood S, Gupta K, Gupta N. Pattern of benign breast lesions on FNAC in consecutive 100 cases: a study at tertiary care hospital in India IJPBS 2013;4:129- 138

8. Baptist SJ, Thomas JA and Kothare SN. Lesions of the breast. J. Indian Med. Assoc 1973; 61(3): 127-131.

9. M Kumar, K Ray, S Harode, DD Wagh. The Pattern of Benign Breast Diseases in Rural Hospital in India, East and Central African Journal of Surgery 2010; 15:.5964

10. Adesunkanmi, A.R., E.A. Agbakwuru, Benign breast disease at Wesley Guild Hospital, Ilesha, Nigeria. West Afr. J. Med.2001; 20: 146 -51.

11. Catherine Goehring and Alfredo Morabia. Epidemiology of Benign Breast Disease, with Special Attention to Histologic Types. Epidemiol Rev 1997;19: 310-327.

12. Malik R, Bhardwaj VK; Breast lesions in young females. A 20- year study for significance of early recognition. Indian $\mathbf{J}$ Pathol Microbiol., 2003; 46(4): 559-562.

13. Jyoti Priyadarshini Shrivastava, Alok Shrivastava. "Fine Needle Aspiration Cytology of Breast Lumps with Clinical and Histopathological Correlation: A 2 Year Study in Gwalior, India". Journal of Evolution of Medical and Dental Sciences 2015; 4: 9729-9734.

14. Chandanwale SS, Gupta K, Dharwadkar AA, Pal S, Buch AC, Mishra N. Pattern of palpable breast lesions on fine needle aspiration: A retrospective analysis of 902 cases. J Midlife Health. 2014 Oct-Dec; 5(4): 186-191

15. Coen P, Kulin H, Ballantine T, Zaino R, Frauenhoffer E, Boal D, et al. An 
aromatase-producing sex-cord tumour resulting in prepubertal gynaecomastia. $\mathrm{N}$ Engl J Med. 1991;324:317-22

16. Predictions - Globocan - iarc globocan. iarc. fr/ Pages/ burden_sel.aspx

17. Pradhan M, Dhakal HP. (2008). Study of breast lumps of 2,246 cases by fine needle aspiration. J Nepal Med Assoc, 47, 205-9.

18. Mayun AA, Pindiga UH, Babayo UD (2008). Pattern of histopathological diagnosis of breast lesions in Gombe, Nigeria. Niger J Med; 17: 159-62.

19. Khan S, Kapoor AK, Khan IU, et al (2003). Prospective study of pattern of breast diseases at Nepalgunj medical college (NGMC). Nepal Kathmandu Univ Med J, 1, 95-100.

20. Balkrishna B Yeole, AP Kurkure. An Epidemiological Assessment of Increasing Incidence and Trends in Breast Cancer in Mumbai and Other Sites in India, During the Last Two Decades Asian Pacific Journal of Cancer Prevention, Vol 4, 2003;51-56. 